\title{
Henry James and the Limits of Historicism
}

\author{
By Ross Posnock, University of Washington
}

"Cultural studies," one of its gifted practitioners has recently remarked, "has had a distinctly difficult time with the concept of aesthetic value. It has done little more than assault, critique, explode, and dismantle it--often for the best of reasons" (Lott 545). But rather than gloat over the success of its campaign against aesthetic value, Eric Lott, perhaps with a twinge of guilty conscience, acknowledges that "we have recognized too little, though, that art and aesthetic activity generally are recognizable human interests, and ought to find a place in cultural studies accounts" (546). This remarkable statement is worth quoting, not least because its earnest tone of generous concession vividly conveys cultural studies' lavish sense of triumph amid the wreckage of the aesthetic. Or so cultural studies would have us believe. But a less predictable tale is told about the recent fate of the aesthetic if we note the surprisingly robust current critical fortunes of a canonical white male elitist, alleged high priest of aesthetic idealism, who seems the virtual embodiment of all that cultural studies targeted for demolition.

Yet Henry James, far from being demolished or, even worse, ignored, has been successfully repositioned in response to the profession's paradigm shift from literary to cultural criticism. This repositioning (a word I borrow from advertising describing the effort to revive products whose shelf life has grown tenuous), moreover, has been conducted in a seamless, indeed painless, and convincing way.

How did Henry James manage not merely to survive but prosper in the new regime? The terms for an answer are suggested by Kaja Silverman's Lacanian [End Page 273] feminist account of James as a radically marginal subject whose sexuality refuses specification. These days, such a 
subject holds considerable power and interest for cultural studies. James consistently locates himself and his fiction precisely at a fissure in the dominant discourse. Such extreme positioning, of course, calls into question an animating premise of cultural studies--that canonical authors are figures of repression, of ideological containment. The inadequacy of this received wisdom is further confirmed by the ease with which Henry James is being assimilated to the terms of the new paradigm (of cultural studies), for this assimilation is neither a result of critical chicanery nor capitulation to fashion, but rather the result of taking James at his own word.

This taking sounds simple but involves a good bit of ground clearing, above all a dismantling of the inert, enshrined formalist Henry James that was erected in the nineteen fifties. Once this sacred icon is set aside, one can begin attending to the textual sites where James ostentatiously unraveled his mastery, that is, punctured the dominant fiction--the "stable core" of unity said to be central to patriarchy and classical masculinity. His acts of de-idealization reverberate in his memoirs and in The American Scene, works that traffic in a dialectic of abjection and power, and deliberately estrange his audience's expectations and orthodoxies. His memoirs enact a curious spectacle: the internationally acclaimed Master of the Novel displaying himself as a "dunce," a "fool" grateful for his brother's crumbs. Henry James celebrates the pleasures of vagueness, envy, blankness, belatedness, and imitation, qualities conventionally believed to be destructive of the self's integrity. The assumption that integrity--a closed, unified stability--inheres in subjectivity is what James contested long before such skepticism became a postmodern article of faith.

Taking James's self-confessed marginality seriously involves relocating The American Scene from the periphery to the center of the James canon, for in this book marginality is most pivotally and performatively on display. The margin at once situates the "restless analyst," as James describes himself, and locates his subject--the United States. A zone of uncertainty, the margin is a veritable quicksand engulfing all pretensions to mastery, control, and stable identity. Standing for neither a "possible greater good" nor "greater evil," the margin is the irreducible fact of the "mere looming mass of the more, the more and more to come" ( $\underline{A S}$ 401). James fashions himself as a marginal man of double consciousness--at once "inquiring stranger" and "initiated native"--who admits that "an inevitable failure to conclude" dogs his efforts to define and fix the "immense fluidity" of America's "margin" ( $A S$ 401). Having 
immersed himself in the vast margin that comprises the United States, James faces a consequence that he poses as a question: "which is the American," he famously asks, "which is not the alien ... where does one put a finger on the dividing line ... ?" (AS 124).

James's uneasy surrender to the visceral fact of the alien as fellow American counts, I think, as the implicit premise of Sara Blair's approach to The American Scene. In other words, Blair's vigorous and inventive contextualizations take as a given a James already busy blurring boundary lines of self and other, already buffeted and exhilarated by acts of projection and identification. Blair's James possesses a critical stance of "productive" ambivalence and a cultural politics [End Page 274] whose "mixed register" promotes "an ethos of openness to racial exchange even as they record vivid urges to conduct, and to resist, racial management." Such strenuous mobility in response to the pressures of affirming the alien is the signature of Jamesian flanerie, and Blair's contextual method finds new ways of making this vivid.

Whereas Jamesians of earlier generations found sustenance in the moral fastidiousness and refinement of consciousness displayed by the characters of James's fiction, Blair appreciates what she dubs James's "civic consciousness" formed from a matrix of messy marginality. That James conceives that consciousness as a "training for freedom" capable of a "more complex openness ... to the claims of otherness" appears to be her major ethical claim on behalf of James. In testing and clarifying that claim by juxtaposing it against rival contemporary projects of racial management and documentation, Blair's methodology recalls New Historicism. Fredric Jameson describes New Historicism as a "montage of historical attractions" (adapting Eisenstein's phrase) and he finds a homological or analogizing process to be the most distinctive formal principle of New Historicist discourse (192). Blair's analogues include Lewis Hine's photographs of Ellis Island immigrants, the phantasmagoric effects of magic lanterns, and the Pullman as a site for "the nation-building energies" James "engages and resists."

All of Blair's homologies are fascinating and undeniably enlarge the discursive field of The American Scene. Yet the admiration one comes away with in reading Blair is mixed with something akin to what Jameson has described as the inevitable "bewilderment" produced by New Historicism's "immanence, the suppression of distance" achieved by saturating the reader in the "detail and immediacy" of heterogeneous 
material (188). What remains unclear for me in Blair's adroit demonstration of James's participation in "racial theatre" is how, ultimately, one is to judge James's relation to African Americans as they are depicted in The American Scene. Does his acrobatic openness, his productive ambivalence, his hyperbolic marginality, finally amount to an elaborate evasion of moral/ethical responsibility about Jim Crow America? More pointedly, is The American Scene a brief against racism, and if not why not?

I pose these blunt questions in the terms of the present discussion, but they derive from the powerful fourth chapter of Kenneth Warren's Black and White Strangers on James, race and The American Scene. Pausing to sketch how Warren approaches this topic might be useful here as a way of measuring the limits of any historicist approach to James. For Warren, James's "contribution to the discourse of race in America is at best ambivalent" (22). Warren is writing from a radically different subject position than Blair. As an African-American critic analyzing James, Howells, and other realists, Warren is acutely sensitive to the political burdens that weigh upon him due to what he calls the "tendency" within African-American criticism (created by the prestige of black vernacular critique exemplified by Houston Baker) "to suppress and discredit internal dissent" by approving only those critics who create "a criticism and politics centered upon . . . black difference" rather than staging confrontations, as Warren does, between white mainstream texts and black works (139). In a climate, says Warren, where pleasure must coincide with one's politics, even to confess publicly to reading and [End Page 275] enjoying James is politically risky: "time spent reading James . . . is admittedly time spent away from the black-authored texts that have been neglected" (141).

At one point Warren ponders a haunting might-have-been--a dialogue between Du Bois and Henry James, whose The American Scene includes a famously condescending notice ofThe Souls of Black Folk, which had been sent him by Du Bois's Harvard mentor William James.

It is easy to imagine how Henry James's reading of The Souls of Black Folks could have been one of the signal moments in American literary history .... As part of James's reintroduction to his native land, The Souls might have suggested an alternate trajectory for The American Scene such that its criticism of a society scored by commercialism might have also become a powerful brief against American racism. William James ... had inveighed publicly against lynching on two separate occasions. (112) 
Warren concludes that Henry James's silence would have been "disappointing" to Du Bois, who had urged readers of The Souls to respond with "thought" and "thoughtful deed" (112). The American Scene, notes Warren, is "nothing if not thoughtful, but its handling of the race problem falls dreadfully short of the clear denunciations of lynching and mob violence that prevailing conditions called for" (113).

However one assesses the fairness of this judgment, it does carry force--its stark, obdurate literalism becomes the ceiling against which shatter all analogical arguments for James's openness as a cultural critic (including those found in my own work on James). One can revel in and demonstrate in ever-ingenious ways the subtleties of James's serpentine negotiation with otherness. But Warren's judgment will remain unmoved and unmovable.

Warren's stance is a clarifying setting of limits, a reality check, to the tendency to overestimate the range of James's empathic powers. But, ultimately, I would dissent from Warren and argue that The American Scene does possess an "alternate trajectory" comprised of a pragmatist commitment to immersion, hazard, contingency, and that this trajectory displays political power and even courage though not precisely of the sort Warren asks for. Although Warren consistently ignores this "alternate trajectory," Du Bois might have admired and valued it. After all, what Henry James and Du Bois have in common is William James, specifically his pragmatism, and particularly its insistence on toppling Olympian authority and embracing what Du Bois called "a certain tingling challenge of risk" (58). Henry James, in my view, prefigures those of a later generation--Du Bois and John Dewey--in enacting a pragmatism that turns aesthetics from contemplation to action that cuts against the grain of capitalist efficiency and utility. ${ }^{1}$ In neglecting this tradition of pragmatist aesthetics, cultural studies not only depends on a caricatured notion of aesthetic value, but foregoes the opportunity to profit from a tradition that resolves the obdurate conflict between aesthetics and politics. 


\section{NOTES}

1. I explore some of these issues in "The Distinction of Du Bois:

Aesthetics, Pragmatism, Politics," and in "Affirming the Alien: The

Pragmatist Pluralism of The American Scene."

KEY TO WORKS BY HENRY JAMES

AS--The American Scene. Bloomington: Indiana UP, 1969.

OTHER WORKS CITED

Du Bois, W. E. B. "My Evolving Program for Negro Freedom." What the Negro Wants. Ed. Rayford Logan. Chapel Hill: U of North Carolina P, 1994. 31-70.

Jameson, Fredric. Postmodernism. Durham: Duke UP, 1991.

Lott, Eric. "The Aesthetic Ante." Callaloo 17 (1994): 545-55.

Posnock, Ross. "Affirming the Alien: The Pragmatist Pluralism of The American Scene." The Cambridge Companion to Henry James. Ed. Jonathan Freedman. Cambridge: Cambridge UP, forthcoming.

----. "The Distinction of Du Bois: Aesthetics, Pragmatism, Politics." American Literary History 7 (1995): in press.

Silverman, Kaja. Male Subjectivity at the Margin. New York: Routledge, 1992.

Warren, Kenneth. Black and White Strangers. Chicago: U Chicago P, 1993. 